\title{
Badania skoncentrowane na dzieciach, badania z udziałem dzieci, dzieci jako badacze. Etyczne i metodologiczne aspekty badań prowadzonych w nurcie nowej socjologii dzieci i dzieciństwa
}

\author{
Paulina Bunio-Mroczek \\ Instytut Socjologii UŁ
}

DOI: https://doi.org/10.18778/1733-8069.17.4.01

\begin{abstract}
Słowa kluczowe: socjologia

dzieciństwa, badania $\mathrm{z}$ udziałem dzieci, badania skoncentrowane na dzieciach, etyka badań, metodologia badań
\end{abstract}

\begin{abstract}
Abstrakt: Badania dzieciństwa, w tym badania z udziałem dzieci, są rozwijającym się obszarem aktywności naukowej, podejmowanej w ramach interdyscyplinarnych nowych studiów nad dzieciństwem (new childhood studies). Obecnie opierają się na koncepcji dziecka jako aktywnego aktora społecznego oraz na prawach dziecka w rozumieniu Konwencji o prawach dziecka ONZ z 1989 roku. Prowadzenie badań skoncentrowanych na dzieciach i badań z udziałem dzieci, a także badań, w których dzieci przyjmują rolę badaczy (są współautorami badań) wymaga pogłębionej refleksji nad etyką i metodologią. Dzieci, jako przedstawiciele grupy mniejszościowej, podlegającej dyskryminacji i marginalizacji, zaliczane są do grupy „wrażliwych” (sensitive) i „nieuprzywilejowanych” (vulnerable) uczestników badań. Artykuł opiera się na analizie literatury przedmiotu i wywiadach eksperckich z badaczami/badaczkami dzieciństwa. W tekście prezentuję ważne etyczne i metodologiczne kwestie badań z udziałem dzieci wraz z przykładami rozwiązań stosowanych w tych obszarach w ramach nowych studiów dzieciństwa.
\end{abstract}

\footnotetext{
Paulina Bunio-Mroczek, dr, pracuje jako adiunkt w Katedrze Socjologii Stosowanej i Pracy Socjalnej, w Instytucie Socjologii Uniwersytetu Łódzkiego. Jej zainteresowania naukowe koncentrują się wokół problemów społecznych i ich rozwiązywania, pomocy społecznej i pracy socjalnej, rodziny i rodzicielstwa oraz wsparcia dla rodzin, rewitalizacji społecznej i gentryfikacji, a ostatnio również socjologii dzieci i dzieciństwa.
}

\author{
Adres kontaktowy: \\ Instytut Socjologii \\ Wydział Ekonomiczno-Socjologiczny \\ Uniwersytet Łódzki \\ ul. Rewolucji 1905 r. 41/43 \\ 90-214 Łódź \\ e-mail: paulina.bunio@uni.lodz.pl
}




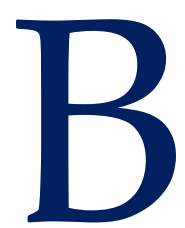

adania dzieciństwa, w tym badania z udziałem dzieci, są rozwijającym się obszarem aktywności naukowej, podejmowanej $\mathrm{w}$ ramach interdyscyplinarnych nowych studiów nad dzieciństwem (new childhood studies). Choć podkreśla się konieczność stosowania inter- lub multidyscyplinarnego podejścia, w ramach samej socjologii powstał również nowy nurt badań dzieciństwa, nazywany „nową socjologią dzieci i dzieciństwa" (new sociology of children and childhood) ${ }^{1}$. Określenie „nowe” w nazwie ukształtowanego na przestrzeni ostatnich dziesięcioleci i umacniającego się paradygmatu podkreśla chęć odcięcia się od wcześniejszych sposobów badania dzieci i dzieciństwa, a także gotowość do zmiany myślenia o pozycji i kompetencjach dzieci jako badanych, o roli dorosłych badaczy w procesie badań z udziałem najmłodszych, o relacjach między nimi, o stosowanych $\mathrm{w}$ badaniach metodach i technikach, a także sposobach analizy danych, interpretacji wyników i rozpowszechniania zdobytej wiedzy.

Badacze i badaczki pracujący w obszarze nowych childhood studies zgadzają się, że badania z udziałem dzieci nie należą do łatwych i wymagają wyjątkowej uważności na każdym etapie realizacji projektu naukowego. Celem artykułu jest zebranie i uporządkowanie istotnych kwestii, z którymi osoby prowadzące empiryczne badania społeczne

\footnotetext{
${ }^{1}$ Rozwój socjologicznego nurtu badań nad dzieciństwem nie znajduje na razie odzwierciedlenia w strukturze Polskiego Towarzystwa Socjologicznego, w którym nie funkcjonuje na ten moment sekcja Socjologii Dzieci i Dzieciństwa. Badania nad dzieciństwem prezentowane są przede wszystkim w ramach prac sekcji Socjologii Życia Rodzinnego i Intymności oraz Sekcji Socjologii Młodzieży i Edukacji. W Europejskim Towarzystwie Socjologicznym od lat 80 . XX w. istnieje sieć badawcza Sociology of Children and Childhood, a od 1995 r. sieć badawcza Youth $\mathcal{E}$ Generation. W Międzynarodowym Towarzystwie Socjologicznym w 1975 r. powstały komitety badawcze Sociology of Childhood i Sociology of Youth (Bunio-Mroczek 2017).
}

z udziałem dzieci muszą się skonfrontować. W tekście skupiam się na dwóch ważnych wymiarach badań skoncentrowanych na dzieciach (child-focused research) i z udziałem dzieci (research with children): etycznym i metodologicznym. Stanowiły one dla mnie wyzwanie, kiedy planowałam badania $\mathrm{z}$ udziałem dzieci $\mathrm{w}$ ramach pilotażowego projektu badawczego dotyczącego doświadczeń tak zwanych „dzieci przekwaterowywanych” (czyli dzieci poddawanych przymusowym przeprowadzkom) $\mathrm{w}$ toku działań z zakresu miejskiej odnowy w procesie rewitalizacji ${ }^{2}$. Przygotowując się do badań z dziećmi, których realizacja w okresie pandemicznego lockdownu opóźniała się, konfrontowałam się z licznymi pytaniami i wątpliwościami dotyczącymi etycznych i metodologicznych aspektów planowanego procesu badawczego. $\mathrm{W}$ artykule zbieram podejścia badaczy dzieciństwa do tych kwestii i prezentuję konkretne, przykładowe rozwiązania. Czasami stanowiska badaczy i badaczek pracujących w ramach nowych childhood studies są jednomyślne, czasami rozbieżne, niekiedy pytania i dylematy pozostają bez jednoznacznych odpowiedzi i muszą być przedmiotem indywidualnych lub zespołowych rozważań i decyzji podejmowanych $\mathrm{w}$ konkretnych sytuacjach $\mathrm{w}$ czasie prowadzenia badań. Podstawą artykułu są wybrane polskoi anglojęzyczne pozycje literatury przedmiotu oraz wywiady eksperckie z osobami realizującymi badania naukowe i projekty partycypacyjne z udziałem dzieci (pięć takich rozmów odbyłam w okresie lockdownu, nie mogąc rozpocząć badań z dziećmi).

\footnotetext{
2 „Dzieci w sytuacji zagrożenia. Opracowanie procedury badawczej do zastosowania w badaniach społecznych z udziałem dzieci doświadczających sytuacji trudnych oraz realizacja pilotażowego badania na temat doświadczeń dzieci przekwaterowywanych $w$ ramach realizacji polityki miejskiej określonej w Gminnym Programie Rewitalizacji (GPR)", praca badawcza dofinansowywana z rezerwy Dziekana Wydziału Ekonomiczno-Socjologicznego dla młodych naukowców.
} 
Tekst, poza w prowadzeniem, zbudowany jest z czterech części. W pierwszej prezentuję nową koncepcję dzieciństwa, która zrewolucjonizowała sposób postrzegania dzieci w społeczeństwie, oraz ukazuję jej wpływ na kształtowanie się nowego paradygmatu badań nad dzieciństwem. W drugiej przedstawiam dzieci jako „wrażliwych” badanych oraz analizuję najistotniejsze kwestie etyczne badań społecznych z udziałem dzieci. Trzecia część artykułu dotyczy metodologii badań skoncentrowanych na dzieciach, prezentuję $\mathrm{w}$ niej stosowane $\mathrm{w}$ badaniach $\mathrm{z}$ udziałem dzieci metody i techniki badawcze, odwołując się do przykładów konkretnych zrealizowanych projektów badawczych. Czwarta część tekstu dotyczy udziału dzieci w projektach naukowych jako badaczy, czyli mało znanej i nierozpowszechnionej formy badań, w których dzieci współpracują z dorosłymi na różnych etapach realizacji projektów naukowych. Na zakończenie prezentuję ogólne wnioski wyprowadzone z badań z udziałem ekspertów, które stanowią rodzaj podsumowania i uwypuklenia istotnych kwestii poruszonych $\mathrm{w}$ artykule.

\section{Nowa koncepcja dzieciństwa i jej implikacje dla badań nad dzieciństwem. Główne założenia new childhood studies}

Badania dzieci i dzieciństwa prowadzone były od dawna, przede wszystkim w obszarze nauk medycznych, psychologii (rozwojowej), pedagogiki, również socjologii, ale długo były to badania „nad” dziećmi, a nie „z” dziećmi lub „dla” dzieci (Corsaro 2015). Dziecko traktowano bardziej w kategorii przedmiotu niż podmiotu badania, co było rezultatem „utrwalonej kulturowo tendencji do bagatelizowania i dewaluowania pozycji nieletnich" (Lisek-Michalska 2012: 40), czyli wynikało z ogólnych tendencji do postrzegania roli i pozycji dziecka w społeczeństwie. W klasycznych socjologicznych ujęciach dzieciństwo sta- nowiło okres w życiu, którego sens sprowadzał się do właściwego przygotowania się do dorosłości. Florian Znaniecki opisywał dzieciństwo w kategoriach "terminowania”, jako rodzaj „okresu kandydatury” (Znaniecki 1993: 47 za Petelewicz 2016: 33), dopiero po zakończeniu którego jednostka stawała się „w pełni” człowiekiem. Przez Emila Durkheima dzieci postrzegane były jako istoty słabe, niekompletne, którymś czegoś brakuje (Durkheim 2005 za Petelewicz 2016). W ujęciu strukturalno-funkcjonalnym Talcotta Parsonsa (1951 za Gabriel 2017) socjalizacja pierwotna stanowiła proces przyswajania przez dziecko wzorów i wartości, norm oraz ról społecznych umożliwiających właściwe odnalezienie się w społeczeństwie jako jednostka dorosła. Ów „embrionalny model" dzieciństwa (Smart i in. 2001 za Gabriel 2017: 20-21), czyli wizja dziecka jako istoty „stawającej się" (becoming), będącej w procesie nieustannej tranzycji, przeobrażającej się $\mathrm{w}$ racjonalnego i kompletnego dorosłego, ugruntowała się również dzięki psychologii rozwojowej, opierającej się na założeniu, że dzieci przechodzą przez następujące po sobie i połączone ze sobą fazy rozwoju, aż do osiągnięcia statusu dorosłego (Piaget 1970 za Gabriel 2017). „Socjalizacyjna” koncepcja dziecka prowadziła do zdychotomizowania relacji między dziećmi a dorosłymi, „prywatyzacji” dzieci (postrzegania ich niemal wyłącznie w kontekście życia rodzinnego), „infantylizacji” dzieci (ograniczania ich możliwości partycypacji) oraz „futurologicznego" widzenia ich (patrzenia na dzieci przez pryzmat ich przyszłej wartości jako dorosłych) (Brzozowska-Brywczyńska 2014).

Erozja referowanego powyżej podejścia do dzieci oraz do badania dzieciństwa rozpoczęła się w latach 60. XX wieku. Za kamień milowy na drodze do rozwoju new childhood studies uważa się publikację w 1962 roku książki pod tytułem Centuries of Childhood: A Social History of Family Life (Cunnin- 
gham 2005 za Gabriel 2017; tytuł polskiego wydania: Historia dzieciństwa). Historyk Phillipe Ariès dowodził w niej, że dzieciństwo nie jest ani „naturalnym”, ani „uniwersalnym” zjawiskiem, lecz różni się w zależności od czasu i miejsca (Gabriel 2017: 15). W latach 60. i 70. XX wieku, w następstwie rozwoju myśli feministycznej oraz teorii i ruchów antydyskryminacyjnych, dzieci zaczęły być postrzegane jako grupa mniejszościowa (Petelewicz 2016), nieposiadająca odpowiedniego zakresu praw, dyskryminowana. Dynamiczny wzrost zainteresowania sytuacją dzieci w społeczeństwie, a w rezultacie rozwój badań nad dziećmi i dzieciństwem, datuje się na lata 90. XX wieku (James, James 2012; Lisek-Michalska 2012; Petelewicz 2016). Punktem wyjścia do ukonstytuowania się nowego paradygmatu studiów nad dzieciństwem stała się publikacja Constructing and Reconstructing Childhood z 1997 roku autorstwa Allison James i Alana Prouta (za James, James 2012). Nowe podejście do badań dzieci i dzieciństwa opiera się na dwóch podstawowych twierdzeniach: po pierwsze, dzieciństwo jest społecznym i kulturowym konstruktem; po drugie - dziecko nie powinno być traktowanie jako członek społeczeństwa in spe (Petelewcz 2016). W nowym paradygmacie badań dzieciństwa (new childhood studies, czasami new sociology of children and childhood) realizuje się badania $\mathrm{z}$ dziećmi albo dla dzieci, a nie nad dziećmi. Świadczy o tym terminologia - badania nazywane są "badaniami skoncentrowanymi na dzieciach" (child-focused research) lub „badaniami z dziećmi” (research with children). Dzieci traktowane są jak podmioty, aktorzy społeczni (social actors) (James, James 2012: 10-12), a ich wiedza, opinie, pomysły, sposoby doświadczania rzeczy wistości znajdują się w centrum zainteresowań badaczy. Uważa się, że przed powstaniem nowego podejścia badawczego do dzieciństwa i zmiany myślenia o dzieciach jako podmiotach badania głosy dzieci były „wyciszane” (muted, Hardman 1973 za Maciejewska-Mroczek 2018: 38). W nowym nurcie badań nad dzieciństwem dzieci postrzegane są jako źródło przyczynowości; podmioty mające możliwość wyboru ról, zadań, sposobów wykonywania pracy, partnerów oraz metod, a także decydowania, czy w ogóle podejmować aktywność, czy też nie (Kondracka 2007 za Lisek-Michalska 2012: 35). Dzieci (współ)konstruują swoje życie i przekształcają swoje środowisko społeczne. „Dzieci, tak samo jak dorośli, zdolne są do kompetentnego działania i kulturowego kreowania otaczającego je świata" (Favretto, Fucci, Zaltron 2018: 80). Nowe studia dzieciństwa charakteryzuje głęboki namysł nad etyką i metodologią prowadzonych badań oraz przekonanie o prymacie bezpieczeństwa i dobrostanu dzieci w czasie realizacji badań $\mathrm{z}$ ich udziałem. Badania skoncentrowane na dzieciach zakładają przyjęcie postawy szacunku wobec dziecka, respektowania i zainteresowania jego perspektywą (standpoint). Wbadaniach zaleca się stosowanie metod i technik partycy pacyjnych (James, James 2012), choć badacze zwracają się również ku klasycznym metodom badań społecznych. Teoretyczno-epistemologiczną ramę dla nowych studiów nad dzieciństwem stanowią często podejścia wywodzące się z teorii społecznego konstruktywizmu, teorii krytycznej, myśli feministycznej i postmodernistycznej, a także idei empowerment. Badania często prowadzone są w nurcie badań zaangażowanych, badań w działaniu (social action research), w których celem jest nie tylko poznanie jakiegoś fragmentu rzeczywistości, ale również przekształcenie jej zgodnie z realizacją idei sprawiedliwości społecznej. Badania społeczne mają sprawić, że głosy słabszych społecznie osób, grup i populacji „zostaną usłyszane" oraz przyczynić się do poprawy sytuacji, jakości życia, pozycji społecznej badanych (Liamputtong 2007). 
Nowe studia nad dzieciństwem traktują dzieciństwo jako złożone, wielowymiarowe zjawisko społeczne, którego zrozumienie nie jest możliwe $\mathrm{z}$ zastosowaniem pojedynczej epistemologicznej perspektywy, w ramach jednej dyscypliny. New childhood studies to obszar badań z założenia interdyscyplinarny. Obejmuje badania prowadzone $\mathrm{w}$ ramach dyscyplin takich jak: biologia, medycyna, psychologia, psychologia społeczna, polityka społeczna, prawo, geografia, pedagogika, sztuka i literatura, historia (z naciskiem na historię społeczną), a przede wszystkim antropologia i socjologia (James, James 2012: 18-21).

Podsumowując, badacze realizujący badania z udziałem dzieci w nurcie nowej socjologii dzieci i dzieciństwa lub szerzej - nowych studiów nad dzieciństwem uważają dzieci za równoprawnych uczestników procesu badawczego i życia społecznego w ogóle. Odwołują się do podmiotowości i kompetencji dzieci, dbają o realizację praw dziecka zapisanych w Konwencji o prawach dziecka z 1989 roku3 ${ }^{3}$, w dziecku - uczestniku procesu badawczego - widzą podmiot, a nie przedmiot badania, aktywnego i pełnoprawnego aktora społecznego. Uważają również, że prowadzenie badań skoncentrowanych na dzieciach wymaga pogłębionej refleksji nad etyką i metodologią.

\section{Dzieci jako „wrażliwi” (sensitive, vulnerable) uczestnicy badań. Etyka badań z udziałem dzieci}

Dzieci i młodzież zaliczani są do grupy badanych „wrażliwych” (sensitive) „nieuprzywilejowanych” (vulnerable), z którymi prowadzi się tak zwane badania „wrażliwe” (sensitive research). Należą do uczestni-

\footnotetext{
${ }^{3}$ Konwencja o prawach dziecka uważana jest za „największe osiągnięcie społeczności międzynarodowej w zakresie ochrony praw dziecka”, będącym „radykalnym odwrotem od podejścia typowo instrumentalnego" wobec dzieci (Mikołajczyk-Lerman 2017: 31).
}

ków badań, do których dostęp jest potencjalnie utrudniony lub mocno ograniczony (hard-to-reach, difficult to access) (Liamputtong 2007). Dzieci uznawane są za mniejszość, grupę marginalizowaną, o ograniczonych prawach, niepełnej możliwości wpływania na swoją sytuację, za populację poddawaną praktykom dyskryminacyjnym, zagrożoną różnymi rodzajami ryzyk społecznych, wykluczoną, słabszą społecznie, „niewidzialną” (hidden, invisible), „niemą" (silent), której głos jest „wyciszany” (muted) (Liamputtong 2007). Przyjmuje się, że na niektóre pytania badawcze odpowiedzieć mogą tylko i wyłącznie „wrażliwi” badani (Liamputtong 2007). Analogicznie uważa się, że wiedza o dzieciństwie i byciu dzieckiem powinna pochodzić przede wszystkim od dzieci. Zdaniem Prenee Liamputtong (2007) badacze i badaczki mogą odczuwać obawę przed angażowaniem się w projekty badawcze $z$ udziałem grup wrażliwych. Badanie może wydawać im się zbyt trudne do zrealizowania, na przykład z powodu trudności z uzyskaniem dostępu do badanych, konieczności zatwierdzenia badań przez komisję etyczną, ograniczonych możliwości uzyskania finansowania lub zmierzenia się z licznymi dylematami o charakterze etycznym. Jednak lęk badaczy przed podejmowaniem pewnych tematów badawczych może jeszcze pogłębić marginalizację ludzi, których te tematy osobiście dotyczą. Prowadzenie badań z udziałem przedstawicieli grup nieuprzywilejowanych jest koniecznym warunkiem udzielania im wsparcia i poprawy jakości ich życia (Liamputtong 2007). „Wrażliwym” uczestnikom badań przede wszystkim trzeba zapewnić bezpieczeństwo (safety) oraz poczucie dobrostanu (well-being) w czasie procesu badawczego i po nim. Decyzja o podjęciu i realizacji badania powinna być podjęta po rozważeniu stosunku korzyści do ryzyka. Badanie powinno przynosić korzyść uczestnikom badania, choć niekoniecznie $\mathrm{w}$ formie materialnej czy finansowej (Liamputtong 2007). 
Jolanta Lisek-Michalska (2012) za dwie najistotniejsze kwestie etyczne występujące w badaniach z dziećmi uważa problem uzyskania ich świadomej zgody (informed consent, a w przypadku osoby niepełnoletniej raczej informed assent) oraz zapewnienie badanym anonimowości i poufności. Oczywiście owych problematycznych kwestii w obszarze badań skoncentrowanych na dzieciach jest więcej, zwłaszcza jeżeli przyjmiemy, że w obszarze badań społecznych mamy do czynienia $\mathrm{z}$ różnymi rodzajami etyki. Jak wskazuje Anna Witeska-Młynarczyk, obok etyki proceduralnej (obejmującej właśnie sprawy związane ze świadomą zgodą na udział w badaniu oraz zapewnieniem badanym anonimowości/poufności) można jeszcze wyróżnić etykę w praktyce (inaczej etykę sytuacyjną, wymagająca podejmowanie decyzji w sytuacjach nieprzewidzianych, czasami nie do końca określonych, niejasnych; Guillemin, Gilliam 2004 za Witeska-Młynarczyk 2018) oraz etykę relacyjną (odnoszącą się do relacji między badanym/badaną a badaczem/badaczką, które powinny opierać się na szacunku, godności, wzajemnym porozumieniu [Ellis 2007 za Witeska-Młynarczyk 2018]).

Uzyskanie świadomej zgody od uczestników badań nie jest proste ${ }^{4}$. W przypadku badań, w których uczestniczą dzieci, ze względu na nierównowagę statusów i władzy występującą zazwyczaj między dorosłymi a dziećmi, a dodatkowo między badacza-

\footnotetext{
${ }^{4}$ Świadoma zgoda może okazać się trudna do uzyskania nawet w przypadku badań z dorosłymi. Czy w ogóle możliwe jest uzyskanie w pełni świadomej zgody na udział w badaniu? Jak wiele informacji na temat badania badacz/badaczka może udzielić przed badaniem, żeby badanie wciąż miało sens, czyli żeby uzyskane $\mathrm{w}$ toku badania dane nie zostały zniekształcone przez opowiedzenie o nim uczestnikom? Czy uczestnicy badania są w stanie ocenić, czy udział w badaniu stanowi dla nich zagrożenie, czy nie? (Ciuk, Latusek-Jurczak 2012 za Bunio-Mroczek 2016). Problem świadomej zgody i inne etyczne dylematy związane $\mathrm{z}$ prowadzeniem badań $\mathrm{z}$ udziałem dorosłych o niskim statusie społeczno-ekonomicznym zostały opisane w kontekście badań na temat wczesnego rodzicielstwa w tzw. „łódzkich enklawach biedy” (Bunio-Mroczek 2016).
}

mi a badanymi, dorośli odpowiedzialni za realizację badań powinni ze szczególną uwagą podchodzić do uzyskania zgody od dziecka. Ewa Maciejewska-Mroczek i Maria Reimann (2016) proponują traktować udzielanie zgody przez uczestniczące w badaniu dziecko jako proces, który w każdej chwili może zostać przerwany lub zawieszony. Dzieci powinny mieć zagwarantowane prawo do wycofania się z badania lub czasowego odwołania swojego uczestnictwa w nim. Dzieci powinny także mieć pewność, że za odmowę lub wycofanie się z badań nie spotkają je (ani ich bliskich)jakiekolwiek konsekwencje. Inicjalny i symboliczny akt wstępnej zgody na udział w badaniu może więc być w każdej chwili anulowany, a badacz/badaczka powinni zachować czujność wobec niewerbalnych komunikatów dziecka (np. spadku zainteresowania, milczenia, zdawkowego udzielania odpowiedzi, machinalnego podejmowania aktywności), ponieważ mogą one świadczyć o niechęci do dalszego udziału w badaniu. Badacze powinni się również upewniać, że dziecko nie zostało poddane naciskowi lub manipulacji ze strony dorosłych (rodziców, nauczycieli, wychowawców, innych otaczających je osób) i w ten sposób skłonione do udziału w badaniu (Maciejewska-Mroczek, Reimann 2016). Dlatego dyskusyjną kwestią w przypadku badań z udziałem dzieci jest płacenie za udział (opiekunom, instytucjom lub samym dzieciom). Wynagrodzenie może bowiem stanowić czynnik wyzwalający presję ze strony dorosłych na udział dzieci w badaniu ze względu na chęć uzyskania korzyści finansowej5.

\footnotetext{
${ }^{5}$ Kodeks dobrych praktyk badań z udziałem dzieci Interdyscyplinarnego Zespołu Badań nad Dzieciństwem wskazuje, że dzieci za udział w badaniu powinny otrzymać podziękowanie (w postaci dyplomu) oraz drobny, symboliczny upominek (Kodeks dobrych praktyk w badaniach $z$ dziećmi... 2018: 31; więcej na temat Kodeksu... w dalszej części tekstu). Inni badacze i badaczki podkreślają, że dzieci żyją w tej samej rzeczywistości co dorośli, w której obowiązują prawa ekonomii, więc za pracę, której rodzajem jest udział w badaniu i poświęcony czas, dzieci powinny otrzymać jakąś formę wynagrodzenia (Myfanwy Morgan i in. 2002 za Maciejewska-Mroczek 2018: 43).
} 
W badaniach Interdyscyplinarnego Zespołu Badań nad Dziećmi formularze zgody podpisywane są nie tylko przez dorosłych (rodziców, opiekunów), ale też przez dzieci (dzieci młodsze „podpisują" je w formie rysunku). Akt podpisania symbolicznie upodmiotawia dziecko, pełni funkcję performatywną (Maciejewska-Mroczek, Reimann 2016).

Kwestie anonimowości i poufności w badaniach społecznych są szeroko dyskutowane i dobrze udokumentowane w wielu opracowaniach, w tym o charakterze podręcznikowym (np. Babbie 1995; Jemielniak 2012). Są również sygnalizowane w kodeksach etycznych badaczy społecznych (np. Kodeks etyki socjologa Polskiego Towarzystwa Socjologicznego, Code of Ethics Amerykańskiego Towarzystwa Socjologicznego, Statement of Ethical Practice Brytyjskiego Towarzystwa Socjologicznego). W związku z prowadzeniem badań z udziałem dzieci chciałabym zwrócić uwage na dwa rodzaje sytuacji, kiedy kwestie anonimowości, poufności i ochrony danych oraz prywatności badanych oraz osób z ich otoczenia mogą stać się wyzwaniem. Skomplikowana i niejednoznaczna w wymiarze etycznym może okazać się sytuacja, w której badacz/badaczka w czasie badania dowiaduje się, że biorącym udział w badaniu dzieciom grozi niebezpieczeństwo, doznają krzywdy z czyjejś strony, cierpią. Jako dorosła osoba zmuszony/ zmuszona jest podjąć decyzję, czy złamać zasady anonimowości i poufności badania, zawodząc zaufanie, którym obdarzyli go/ją badani, czy też zachować informację dla siebie, pozostawiając dzieci same sobie w trudnej, czasami dramatycznej sytuacji. Za przykład rozwiązania tej kwestii zastosowanego w konkretnym projekcie badawczym może posłużyć procedura, jaką wy pracowali badacze realizujący badanie na temat przekonań dotyczących zdrowia wśród dzieci i młodzieży. Bada- cze uznali, że istnieje duże prawdopodobieństwo, że w czasie badań ich niepełnoletni uczestnicy ujawnią swoje trudne doświadczenia, na przykład opowiedzą o byciu ofiarami przemocy seksualnej i fizycznej oraz o podejmowaniu zachowań ryzykownych (np. o zażywaniu nielegalnych substancji psychoaktywnych). Zgodnie z przepisami prawa, badacze byliby zobowiązani przekazać uzyskane informacje odpowiednim służbom. Stałoby to jednak w sprzeczności z poufnością i anonimowością badań, które chcieli zagwarantować swoim badanym. Badacze zdecydowali, że przed badaniem będą bardzo wyraźnie informować dzieci, że jeśli te ujawnią pewne sprawy, to będą one musiały zostać zgłoszone odpowiednim instytucjom/ organom władzy. Badacze zastosowali rozwiązanie, które, ich zdaniem, najlepiej chroniło interesy uczestników badania: dzieci same mogły podjąć decyzję, czy chcą ujawnić trudne fakty ze swojego życia, a jednocześnie były świadome, że opowiadając o nich, decydują się na uruchomienie procedury powiadomienia służb społecznych (France i in. 2000 za Liamputtong 2007). Inną etycznie wrażliwą kwestią związaną z poufnością, na którą być może rzadziej zwraca się uwagę, jest możliwość ujawnienia przez uczestników badań informacji wrażliwych o innych osobach (np. członkach rodziny, sąsiadach, członkach lokalnej społeczności) (Liamputtong 2007). W czasie badania może dojść do naruszenia prywatności innych osób spoza bezpośredniego grona uczestników badania. W czasie badań z udziałem dzieci dziecko może przedstawić „wrażliwe dane” dotyczące rodziców, dziadków, sąsiadów, nauczycieli, kolegów i koleżanek lub innego badacza/badaczki, z którym/którą miało wcześniej do czynienia. Według Jamesa M. Henslina (2001 za Liamputtong 2007) takie sytuacje $\mathrm{w}$ badaniach jakościowych są nieuniknione, a jednocześnie bardzo problematyczne, zarów- 
no dla osób prowadzących badanie, jak i w nich uczestniczących. Choć zachowanie uczestników badań w dużej mierze znajduje się poza kontrolą badacza, zalecane jest uświadamianie badanych, że w trakcie badania mogą naruszyć prywatności osób, na temat których się wypowiadają. Wydaje się zatem, że osoby realizujące badania z udziałem dzieci powinny być przygotowane na przeprowadzenie krótkiej rozmowy na temat udzielania przez dzieci informacji o znajomych, członkach rodziny, nauczycielach i innych osobach. Zasadę ochrony prywatności innych można zaproponować jako element kontraktu zawieranego z uczestnikami badania przed jego rozpoczęciem.

Nawiązując do drugiego z wyróżnionych powyżej rodzajów etyk, etyki relacyjnej, istotną kwestią występującą w badaniach z udziałem dzieci, organizowanych i prowadzonych przez dorosłych, jest nierówność (nierównowaga) sił, statusów, władzy między badaczami a badanymi (power imbalance, Liamputtong 2007: 27). W literaturze przedmiotu podkreśla się podwójnie nieuprzywilejowaną pozycję dziecka będącego uczestnikiem badania: po pierwsze, ze względu na to, że jest osobą badaną, po drugie - bo jest przedstawicielem grupy mniejszościowej, z mniejszym dostępem do wiedzy i ograniczoną możliwością wyrażania własnych opinii (Maciejewska-Mroczek 2018: 45). Dorosły $\mathrm{w}$ relacji z dzieckiem naturalnie występuje jako strona, która ma władzę, kontroluje przebieg interakcji, decyduje o jej początku, zakończeniu, formie. Między dorosłym a dzieckiem występuje „asymetria biografii” (Witeska-Młynarczyk 2018: 71). Ze względu na tę nierównowagę dziecko może się czuć zobowiązane do odpowiadania na każde pytanie dorosłego, udzielania wyczerpujących odpowiedzi, skrzętnego wypełniania poleceń i realizowania wszystkich zaproponowanych przez do- rosłego aktywności. Jednakże nie należy traktować dzieci jako bezsilnych i bezwolnych uczestników badań, którzy nie są w stanie zdecydować i zakomunikować, co jest dla nich dobre, a co złe: „warto pamiętać, że dzieci dysponują rozmaitymi środkami, żeby powiększać obszar własnej autonomii i wpływać na badanie, i używają sposobów nieraz nieprzewidzianych przez badaczy, a czasem przez nich niepożądanych" (Maciejewska-Mroczek 2018: 46). Badacze pracujący w nurcie nowych childhood studies postulują „niehierarchiczne podejście do relacji z dziećmi" (Maciejewska-Mroczek 2018: 45). W badaniach z dziećmi należy „unikać wszelkich form dominacji" (Witeska-Młynarczyk 2018: 72), na przykład poprzez przyjęcie roli „osoby uczącej się od innych, a nie kontrolującej" (Witeska-Młynarczyk 2018: 72). Jednym ze sposobów, jakie stosują badacze stosujący metody etnograficzne, jest bycie „jak najmniej dorosłym" (the least adult) (James, James 2012; Corsaro 2015). "Ograniczona dorosłość" wymaga "całkowitego zanurzenia się w świecie dzieci, porzucenia dorosłego zwyczaju dominacji (Witeska-Młynarczyk 2018: 75). Niektórzy badacze dzieciństwa uważają jednak takie podejście za niewłaściwe, uważając, że dorosły jest dorosłym i nie ma sensu (a być może również nie jest uczciwe) udawać, że nim nie jest ${ }^{6}$.

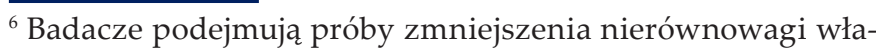
dzy między dzieckiem a dorosłym poprzez, na przykład, realizację badania $\mathrm{w}$ miejscu, w którym dziecko czuje się swobodnie, a badacz nie (np. w domu dziecka) (Maciejewska-Mroczek 2018). Przedsięwzięcie takie może okazać się trudne organizacyjnie, szczególnie w okresie pandemii. Część dzieci może też swobodniej czuje się poza domem, na przykład jeśli mają złe relacje z członkami rodziny lub wychowują się $\mathrm{w}$ rodzinie $\mathrm{z}$ problemami, np. uzależnienia lub przemocy wewnątrzrodzinnej. Badacze zazwyczaj starają się nie organizować badań w szkole lub innym otoczeniu kojarzącym się dzieciom z hierarchicznym układem władzy dorosłych i podporządkowaniem dzieci, komplementarnymi rolami nauczyciel-uczeń, wychowawca-wychowanek (por. np. Maciejewska-Mroczek 2018). Gdy badania z pewnych względów jednak odbywają się szkole, badacze starają się przearanżować przestrzeń tak, aby tworzyła ona nowy kontekst, stała
} 
Bliska relacja między badaczami a badanymi rodzi kolejny rodzaj ryzyka dla tych drugich. Format kontaktu między badaczami a badanymi (na co oczywiście wpływa wybór metodologii badania) buduje atmosferę i relację uczestników procesu badawczego. Generalnie zakłada się, że im swobodniej czuje się uczestniczące w badaniu dziecko, tym lepiej. Familiarna, przypominająca naturalne spotkanie znajomych lub wręcz przyjaciół atmosfera badania niesie jednak ryzyko zapomnienia, że badani w istocie biorą udział w badaniu (szczególnie w badaniach o charakterze etnograficznym, gdzie badacz/badaczka spędza dużo czasu z badanymi oraz gdy wchodzą oni w długotrwałe, partnerskie relacje). W takiej sytuacji badani, a zwłaszcza dzieci, moga powiedzieć i pokazać badaczom więcej, niż by tego chcieli, a później tego żałować (unintended disclosure of intimate knowledge, Hensin 2001: 25 za Liamputtong 2007: 27).

\section{Anna Brzezińska i Zuzanna Toeplitz (2007:} 323-326) w książce o dylematach etycznych w badaniach psychologicznych z dziećmi powołują się na standardy etyczne badań z udziałem dzieci amerykańskiego Society for Research in Child Development [Stowarzyszenie Badań nad Rozwojem Dziecka]. Poniżej zaprezentowałam je w punktach, przeformułowując je w pewnym zakresie i dostosowując ich treść do realiów badań społecznych. $\mathrm{W}$ badaniach $\mathrm{z}$ udziałem dzieci: (1) nie wolno stosować szkodliwych procedur (takich, które mogłyby wywołać fizyczną lub psychiczną krzywdę dziecka); (2) konieczne jest uzyskanie dobrowolnej

się jednak innym miejscem, niekojarzącym się z jej codzienną funkcją („chodziło o stworzenie warunków różniących się w możliwie największym stopniu od tych panujących w przestrzeni typowej dla sali lekcyjnej, tak by badacz miał możliwość wynegocjowania z dziećmi jak najlepszego wykorzystania dostępnej przestrzeni, choć w ramach strukturalnych ograniczeń miejsca" [Favretto i in. 2018: 88]). zgody mającego wziąć udział w badaniu dziecka (dziecko powinno zostać kompleksowo i w sposób dla niego zrozumiały poinformowane o badaniu, mieć możliwość uzyskania odpowiedzi na wszystkie swoje pytania dotyczące procedury badawczej, mieć możliwość odmowy lub wycofania się z badania w jego trakcie); (3) konieczne jest również uzyskanie zgody na udział dziecka w badaniu od jego rodziców lub innych opiekunów prawnych, przy czym ich odmowa nie może powodować żadnych negatywnych konsekwencji dla dziecka ani dorosłych; (4) konieczne jest uzyskanie zgody wszystkich innych osób biorących udział w badaniu (np. jeżeli dziecko jest obserwowane podczas lekcji w szkole, powinna to być zgoda towarzyszących mu w klasie innych uczniów i prowadzącego lekcję nauczyciela); (5) zachęcające dziecko do udziału w badaniu „Wzmocnienia” powinny być wyważone i stosowane proporcjonalne do danej sytuacji; (6) jeżeli w badaniu występuje konieczność celowego wprowadzenia badanego w błąd (np. w przypadku eksperymentu), należy skonsultować pomysł na badanie z innymi ekspertami (pytając, czy na pewno jest to właściwa metoda, jakie są implikacje jej zastosowania), a po badaniu wyjaśnić jego uczestnikom, w jakim celu zostali wprowadzeni w błąd; (7) należy zapewnić badanym anonimowość oraz poufność procesu badawczego; tylko uzgodnione $\mathrm{z}$ badanymi informacje mogą zostać użyte przez badaczy w sposób, na który badani wyrazili zgodę; (8) przed rozpoczęciem badania należy zawrzeć kontrakt określający wzajemną odpowiedzialność uczestników procesu badawczego; (9) jeżeli badacz w toku badania dowiaduje się, że dobro dziecka jest zagrożone, należy podjąć właściwe działania; badacz powinien $\mathrm{w}$ takiej sytuacji porozmawiać z rodzicami dziecka, opiekunami, innymi ekspertami od spraw dziecka, tak aby dziecku udzielono właści- 
wego wsparcia; (10) jeżeli w toku badań okaże się, że badanie przynosi badanym niepożądane konsekwencje, należy natychmiast wprowadzić takie zmiany, żeby w przyszłości ich unikać lub zaniechać badania; (11) badacza obowiązuje tajemnica zawodowa, czyli jest zobowiązany do utrzymania $\mathrm{w}$ tajemnicy informacji o uczestnikach badania, dotyczy to oczywiście również dzieci; (12) badacze mają obowiązek wyjaśnić nieporozumienia, które pojawiły się w trakcie badań; (13) badacze powinni poinformować badanych o wynikach badań $\mathrm{w}$ takiej formie, żeby były zrozumiałe dla badanych; (14) badacze prezentując wyniki swoich badań oraz wynikające z nich rekomendacje, powinni zachowywać ostrożność oraz pamiętać o społecznych, politycznych i ludzkich konsekwencjach swoich badań i upowszechniania ich wyników. Mogą pojawić się okoliczności, kiedy „Wartości ogólnonaukowe lub ogólnoludzkie” usprawiedliwiają zatajenie wyników.

Jeden z artykułów Kodeksu etyki socjologa Polskiego Towarzystwa Socjologicznego (2012, art. 16) poświęcony został $\mathrm{w}$ całości badaniom $\mathrm{z}$ udziałem dzieci: "Szczególnej staranności wymagają badania zudziałem dzieci. Oprócz zgody rodziców lub opiekunów prawnych należy również starać się uzyskać zgodę dziecka. Badacze powinni wykorzystać swoje umiejętności tak, by podawane informacje pozostawały dla dziecka zrozumiałe oraz samemu osądzić, czy dziecko jest w stanie zrozumieć zadawane mu pytania. Jeżeli jest to wskazane, należy zasięgnąć porady specjalisty". Pełnym cennych wskazówek i odwołującym się do wszystkich etycznych wymiarów badań z udziałem dzieci dokumentem jest Kodeks dobrych praktyk w badaniach $z$ dziećmi prowadzonych z perspektywy nauk społecznych (w tym interdyscyplinarnych childhood studies, etnografii, antropologii kulturowej, socjolo- gii, stworzony przez Interdyscyplinarny Zespół Badań nad Dzieciństwem (2018, opublikowany również na stronie internetowej $\mathrm{IZBnD}^{7}$ ).

Kodeksy etyczne oczywiście nie zawsze są w stanie zaoferować konkretne rozwiązania złożonych i wielowymiarowych sytuacji zachodzących w procesie badań z udziałem dzieci. Nawiązując do koncepcji „etyki sytuacyjnej”, Anna Witeska-Młynarczyk (2018) podkreśla, że etyczne prowadzenie badań z dziećmi wymaga czytania na bieżąco aktualnej sytuacji, która zachodzi w trakcie badania między badaczami a badanymi, reagowania na zachowanie dzieci, improwizacji, podejmowania większości decyzji „na gorąco”, na miejscu. Udział dzieci w badaniu powinien obywać się „w warunkach sytuacyjnie wrażliwych sądów etycznych" (Crow i in. 2011: 30 za Witeska-Młynarczyk 2018: 70).

Z rozwiązywaniem problemów natury etycznej, ale też na przykład metodologicznej, badacze dzieciństwa (a także prowadzący inne badania „wrażliwe") radzą sobie, tworząc zespoły konsultacyjne („grupy odniesienia” - reference groups) (Booth, Booth 1994: 40 za Liamputtong 2007: 29), w ramach których mogą omówić konkretne sytuacje i dać wyraz swoim emocjom oraz uzyskać wsparcie informacyjne i emocjonalne. W skład takiej grupy mogą wchodzić na przykład: specjaliści pracujący z przedstawicielami badanej populacji (np. psycho$\log$ dziecięcy, pedagog, socjoterapeutka, asystent rodziny, wychowawca świetlicy środowiskowej), inni badacze mający doświadczenie $\mathrm{w}$ badaniach z udziałem dzieci lub innych badaniach „wrażliwych", przedstawiciele badanej populacji.

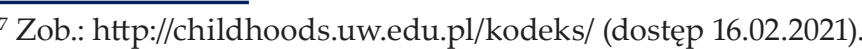


Podsumowując, w badaniach z udziałem dzieci obowiązuje absolutny prymat dobra dziecka nad korzyścią wynikającą z realizacji badań. Badanie nie powinno dojść do skutku lub powinno zostać przerwane, kiedy istnieje możliwość, że zaszkodzi dziecku. Odpowiedzialność etyczna badacza/ badaczki nie kończy się wraz ze sfinalizowaniem etapu zbierania danych. Do nie mniej znaczących i wrażliwych etycznie kwestii należy sposób analizy zebranego materiału, formułowanie wniosków i upowszechnianie rezultatów badania. Odpowiedzialność badacza rozciąga się na właściwe zaprezentowanie wyników badań tak, aby nie skrzywdzić badanych i nie pogłębić ich marginalizacji ani nie stworzyć ich negatywnego obrazu. W ramach nowych badań nad dzieciństwem pojawia się postulat przedstawienia wyników badań z ich udziałem dzieciom, oczywiście w formie dla nich zrozumiałej. Kwestie etyczne w badaniach z udziałem dzieci są pierwszoplanowe, ale jednocześnie przenikają wszystkie inne wymiary badań: metodologiczne oraz organizacyjno-praktyczne.

\section{Metodologia badań z udziałem dzieci. Badania jakościowe, klasyczne metody i techniki, badania partycypacyjne}

Metodologie badań skoncentrowanych na dzieciach i z udziałem dzieci są wy prowadzane z koncepcji dzieciństwa i dziecka funkcjonującej w ramach nowych studiów nad dzieciństwem. Biorące udział w badaniu, dziecko nie jest przedmiotem, lecz aktywnym uczestnikiem badania. Jak podkreślają Favretto i współpracownicy (2018: 81), „uznanie dzieci za aktywne i kompetentne podmioty uczestniczące $w$ budowaniu otaczającego je świata wymaga przyjęcia podejścia badawczego uwydatniającego i podkreślającego punkt widzenia dzieci".
Za najodpowiedniejsze do badań $\mathrm{z}$ udziałem „wrażliwych” badanych, którymi są dzieci, uważa się metody i techniki jakościowe. $W$ badaniach jakościowych badacz/badaczka mają możliwość „dostrojenia się" do badanego. Metody i techniki jakościowe są otwarte (open-ended), mało ustrukturyzowane, elastyczne, mogą być na bieżąco dostosowywane do sytuacji, ich scenariusze moga być płynnie zmieniane, modyfikowane w odpowiedzi na przebieg spotkania $z$ badanymi i ich kondycję w danym momencie. Podejście jakościowe umożliwia poznanie i zrozumienie sposobów doświadczania rzeczywistości przez badanych. Za pomocą badań jakościowych dowiadujemy się nie tylko „jak jest”, ale również „jak do tego doszło", „dlaczego tak się stało”, „czym [dany fakt, wydarzenie, proces] jest”, ,jakie jest jego znaczenie" (Hesse-Bieber, Leavy 2005 za Liamputtong 2007: 7). W toku realizacji badań jakościowych grupy i populacje „uciszane”, marginalizowane, społecznie słabsze mogą wyrazić swoje stanowisko i opowiedzieć swoje historie (Liamputtong 2007). Należy jednak zaznaczyć, że w nurcie new childhood studies podkreśla się również znaczenie prowadzenia badań ilościowych (sondażowych, demograficznych, historycznych, realizowanych na poziomie makro, na dużych, reprezentatywnych próbach), które dostarczają cennych danych umożliwiających na przykład badanie wielowymiarowej jakości życia dzieci, a także pozwalają zidentyfikować czynniki wpływające na sytuację dzieci w różnych społeczeństwach, kulturach i okresach (Corsaro 2015).

Na poziomie mikro w ramach nowych studiów na dzieciństwem odchodzi się od tradycyjnych technik pomiarowych z użyciem kwestionariuszy, arkuszy obserwacji i testów, idąc w stronę metod „przyjaznych dziecku” (child-friendly methods), 
z dużym naciskiem na techniki partycypacyjne. Pojęcie child-friendly (przyjazny dzieciom) oznacza „odpowiadający na potrzeby odczuwane i wyrażane przez dzieci" (James, James 2012: 13-14). Rzeczy/zjawiska przyjazne dzieciom niekoniecznie muszą oznaczać to, co dorośli uważają za bezpieczne, słuszne, właściwe i rozwijające dla dzieci (James, James 2012). Określenie to używane jest również w innych kontekstach, na przykład „miasto przyjazne dziecku" - program UNICEF, który ma upowszechniać realizację zapisów Konwencji o prawach dziecka poprzez polityki miejskie (por. Bunio-Mroczek 2021). Maria Reimann podkreśla, że badania z udziałem dzieci wymagają poszukiwania metod badawczych, które lepiej dostosowują się do świata i sposobu komunikowania dzieci, ułatwiając im wypowiedzenie się (Reimann 2018: 139). Stąd stosowanie technik takich jak rozmaite ustrukturyzowane aktywności, często o charakterze działań artystycznych, na przykład rysowanie, malowanie, lepienie, tworzenie kolaży, lub polegających na dokumentowaniu rzeczywistości z perspektywy uczestników badań poprzez tworzenia nagrań (dźwięków, obrazów, filmów). Do rekomendowanych technik badawczych należą również takie, w których dzieci mogą być aktywne fizycznie, pozostawać w ruchu, na przykład spacery badawcze. Wybór partycypacyjnych form prowadzenia badań ma doprowadzić do zniwelowania różnic statusów i władzy między dzieckiem a dorosłym w sytuacji badania (Lange, Mierendorff 2009 za Gabriel 2017: 24). Jednocześnie w badaniach z udziałem dzieci coraz częściej stosuje się „dorosłe” metody i techniki, wcześniej uznawane za nieodpowiednie dla najmłodszych badanych, takie jak kwestionariusze, wywiady (indywidualne, w parach, grupowe), winiety, obserwacje uczestniczące, pisemne wypowiedzi, pamiętniki (Lange, Mierendorff 2009 za Gabriel 2017:
$24)^{8}$. Favretto i współpracownicy zwracają uwagę, że nie sama technika, a sposób jej zastosowania sprawia, że nadaje się ona do pracy z dziećmi: „To nie narzędzia mają być inne, ale raczej postawa epistemologiczna i forma relacji, którą kształtują warunki badania" (Favretto i in. 2018: 93). W badaniach z dziećmi postuluje się przyjęcie postawy „metodologicznej niedojrzałości”, wiążącej się z dostrzeżeniem, że proces badawczy w tym wypadku jest wrażliwy i niepewny (Gallacher, Gallager 2008 za Witeska-Młynarczyk 2018). William A. Corsaro (2015) zaleca wybór takich metod i technik badawczych, które skrócą dystans osobisty i społeczny dzielący dorosłych - badaczy i dzieci - badanych, a przede wszystkim zmniejszą dysproporcję władzy i kontroli wynikającej z różnicy statusów dziecka i dorosłego. Za metody, które szczególnie dobrze służą stworzeniu dzieciom właściwych warunków do wyrażania przez nie opinii, podzielenia się wiedzą i opowiedzenia o swoich doświadczeniach, uważa się metody jakościowe mało ustrukturyzowane, pozwalające na duży poziom elastyczności, zmienności oraz nawiązanie swobodnej relacji, skrócenie dystansu między badanymi a badaczami, a czasami prowadzące też do rozmycia lub odwrócenia ról pomiędzy badanymi a badaczami. Corsaro (2015) zaleca stosowanie metod takich jak nieformalne wywiady prowadzone $\mathrm{w}$ bezpośrednim kontakcie $\mathrm{z}$ badanymi oraz metody etnograficzne.

W literaturze przedmiotu znajdujemy wiele opisów metodologii badań z udziałem dzieci. Przykładowo, $\mathrm{w}$ projekcie badawczym dotyczącym zdrowia dzieci realizowanym przez Interdyscyplinarny Zespół Badań nad Dzieciństwem UW łączono wiele

\footnotetext{
$\overline{{ }^{8} \text { Dzieci powyżej } 11}$ r.ż. uważane są za zdolne do wypełniania standaryzowanych wywiadów kwestionariuszowych (Scott 2008 za Corsaro 2015).
} 
różnych metod i technik badawczych, dostosowując ich przebieg do sytuacji danego badania oraz modyfikując scenariusze badań na podstawie wcześniejszych doświadczeń. Stosowano między innymi wywiady grupowe zogniskowane wokół zaaranżowanych przez badaczy zadań/aktywności wykonywanych przez dzieci indywidualnie lub wgrupach, następnie wspólnie z badaczkami omawianych. Należało do nich rysowanie, mapowanie, uzupełnianie tabel, storytelling, fotografowanie, tworzenie ulotek dla innych dzieci (Maciejewska-Mroczek 2018); obserwacja, wywiad, winiety (Boni 2018); rysunki, kolaże, odgrywanie scenek, dyskusja (Reimann 2018). Warto podkreślić, że prace dzieci (np. plastyczne, fotograficzne, opowieści) albo mogą być same w sobie przedmiotem interpretacji, albo mogą służyć za pretekst do rozmowy z dziećmi, sposób na wywołanie ich wypowiedzi, punkt wyjścia do dyskusji. Maria Reimann wprowadza rozróżnienie na powstałe podczas badań „rysunki”, czyli skończone rzeczy, które są poddawane analizie, oraz „rysowanie” (czynność) będące częścią procesu, elementem spotkania z dziećmi, czymś, co ułatwia dowiedzenie się czegoś, zrozumienie czegoś przez badaczki/badaczy (Reimann 2018: 139-140). W badaniach dotyczących doświadczenia powodzi przez dzieci Walker i współpracownicy (2012) również zdecydowali się połączyć kilka technik badawczych. Badania zrealizowano poza szkoła, w miejscu atrakcyjnym dla dzieci, a przed właściwym badaniem zorganizowano szereg zabaw, w których tematem przewodnim była woda (wcześniej skonsultowano scenariusz badania i proponowane aktywności z nauczycielami dobrze znającymi dzieci i wiedzacymi, które dzieci w jakim stopniu ucierpiały w czasie powodzi). Dzieci poproszone były o przedstawienie swojej historii doświadczenia powodzi (flood journey) za pomocą scenorysów (storyboards), które składały się z kilku „ujęć” (,klatek filmowych”) ukazujących różne etapy powodziowych doświadczeń autorów i autorek. Rysunki stały się pretekstem do rozmów podczas 15-20-minutowych wywiadów indywidualnych oraz dłuższych wywiadów grupowych. Badania z dziećmi uzupełniono czterema wywiadami telefonicznymi z młodymi dorosłymi, dotkniętymi przez tę samą powódź, oraz z osiemnastoma dorosłymi, którzy w czasie i po powodzi udzielali dzieciom wsparcia.

Jako przykład badania z udziałem dzieci wymagającego długoterminowego zaangażowania badaczy i powtarzającego się, regularnego kontaktu z badanymi może posłużyć badanie dotyczące rozumienia płci kulturowej przez dzieci (Davies 1989 za Corsaro 2015). Zrealizowano je poprzez utworzenie "grup naukowych" (study groups) składających się z dzieci obu płci z piątej i szóstej klasy szkoły podstawowej. Grupy te spotykały się z badaczami raz w tygodniu przez 90 minut, przez okres całego roku szkolnego. W ramach spotkań badacze proponowali dzieciom różnorodne aktywności, takie jak dyskusje, pokazywanie sobie zdjęć rodzinnych i opowiadanie o nich, robienie zdjęć jednorazowymi aparatami fotograficznymi, robienie kolaży, słuchanie tradycyjnych i feministycznych opowieści, pisanie opowiadań i autobiografii. Metody typowo etnograficzne, wymagające długiego, trwającego miesiące, czasami nawet lata, przebywania „w terenie”, są również wybierane przez badaczy dzieci idzieciństwa pracujących w nurcie new childhood studies. W badaniach nad interakcjami i kulturą rówieśniczą przedszkolaków William Corsaro (2015) spędzał czas wśród dzieci przedszkolnych w USA i we Włoszech. Próbując uzyskać „status uczestnika" w grupie kilkulatków, stanął przed wieloma wyzwaniami i wypracował różnorodne sposoby postępowania, aby nie być traktowanym przez dzieci jako "typowy dorosły”. Okazało się, że owe 
sposoby musiały zostać zróżnicowane w zależności od kontekstu kulturowego i językowego. Obserwowanie przedszkolaków w ich codziennej zabawie umożliwiło badaczowi identyfikację strategii dzieci przyjmowanych w zabawie, które dorośli interpretują zupełnie odmiennie (i na przykład karzą za ich użycie albo próbują je zmienić) niż same praktykujące je dzieci (Corsaro 2015). Na gruncie polskich badań z udziałem dzieci metody etnograficzne stosuje Anna Witeska-Młynarczyk (2018), na przykład w badaniu z udziałem chłopca z ADHD, w warstwowym opisie którego autorka relacjonuje długotrwały, złożony i nieoczywisty proces uzyskiwania dostępu do pola badawczego, samego uczestnika badania, a także funkcjonowania badaczki w instytucji, w której badanie było realizowane, oraz pokonywania oporu i wchodzenia w sojusze $\mathrm{z}$ chroniącymi dziecko (i/lub siebie samych) „odźwiernymi” (gatekeepers) (Witeska-Młynarczyk 2018).

Podsumowując, orientacja metodologiczna badań skoncentrowanych na dzieciach i z udziałem dzieci jest odzwierciedleniem przyjętej koncepcji dzieciństwa jako społeczno-kulturowego konstruktu oraz dziecka jako podmiotu i aktora społecznego. Obecnie w badaniach z zakresu nowej socjologii dzieci i dzieciństwa stosuje się zarówno klasyczne, jak i nowe, partycypacyjne metody i techniki. Badania jakościowe, szczególnie etnograficzne, uznawane są za najwłaściwsze, by zrealizować cel badań z udziałem dzieci, czyli „poznanie świata dzieci, ich sposobów rozumienia rzeczywistości" (Maciejewska-Mroczek 2018: 56).

\section{Dzieci-badacze (children as researchers). Dzieci jako (współ)autorzy badań}

Niektórzy badacze dzieciństwa decydują się włączać dzieci w proces badawczy. Dzieciom propo- nuje się rolę „asystentów”: pomagają uzyskać dostęp do badanych, realizować badania $\mathrm{w}$ terenie lub wspierają dorosłych badaczy $\mathrm{w}$ interpretacji zgromadzonych danych. W ten sposób dzieci stają się nie tylko współuczestnikami procesu badawczego, ale też współtwórcami badania i jego wyników (Corsaro 2015). Przykładowo, w badaniu na temat doświadczania szkoły przez afroamerykańskich uczniów badaczce pomagał 12-letni chłopiec. Był jej „przewodnikiem” w świecie swoich rówieśników. Tłumaczył niezrozumiałe dla niej kwestie związane z kulturą, słownictwem i muzyką swojej grupy rówieśniczej, a także wraz z badaczką zaplanował treść badania (np. dyspozycje do wywiadów) (Ferguson 2000 za Corsaro 2015). W badaniu z udziałem "dzieci ulicy" w Brazylii to dzieci realizowały wywiady z innymi dziećmi. Dorośli badacze dostrzegli, że dzieci zadawały pytania i kierowały rozmowę na tematy, które im samym nie przyszłyby do głowy (Hetch 1998 za Corsaro 2015).

W przypadku znakomitej większości przedsięwzięć badawczych, które dotyczą dzieci i dzieciństwa, to dorośli wybierają i precyzują temat badań, decydują o stosowanych metodach i technikach badawczych, określają, które dzieci wezmą udział w badaniach, mają kontrolę nad procesem zbierania danych, ich analizy, nad formułowaniem wniosków z badań oraz prezentowaniem ich różnym odbiorcom (James, James 2012). Niektórzy przedstawiciele nauk społecznych uważają, że prawo do uczestnictwa dzieci w życiu społecznym będzie realizowane $\mathrm{w}$ pełni dopiero wtedy, kiedy dzieci będą planować i realizować badania ich dotyczące, pełniąc $w$ nich takie same role jak dorośli naukowcy. Zwolennicy prowadzenia badań z udziałem dzieci jako badaczy (children as researchers) uważają, że dzieci posiadają potrzebne do bycia badaczem 
umiejętności, ponieważ w ramach realizacji szkolnych zadań uczą się gromadzić, selekcjonować i prezentować informacje (Alderson 2008 za James, James 2012). Wykorzystując swoją perspektywę, dzieci mogą formułować inne niż dorośli, celniejsze i bardziej przydatne dla procesu badawczego pytania badawcze (Alderson 2008 za James, James 2012).

Idea włączania dzieci w badania naukowe już nie tylko w roli aktywnych respondentów, których perspektywę warto poznać, ale również jako badaczy, a więc współautorów badań, wyprowadzona jest z podejścia antydyskryminacyjnego i badań zaangażowanych społecznie (action research, social action research, participatory action research, czyli badań w działaniu). $\mathrm{W}$ tej perspektywie badania stanowią z założenia rodzaj politycznego aktu. Są działaniem podkreślającym i umacniającym prawa dzieci, realizującym idee empowerment, partycypacji dzieci w życiu publicznym oraz rzecznictwa na rzecz dzieci (Jones 2004). Przedstawiciele nowych childhood studies podkreślają, że ruch na rzecz uczestnictwa dzieci $\mathrm{w}$ badaniach $\mathrm{w}$ roli badaczy powinien być interpretowany szerzej, jako ruch na rzecz poszerzania partycypacji społecznej dzieci w ogóle i wzmacniania ich prawa do bycia wysłuchanymi (James 2007 za James, James 2012). Uczestnictwo $\mathrm{w}$ projekcie badawczym może stać się dla dziecka pozytywnym, ciekawym i wzmacniającym (empowering) doświadczeniem (Alderson 2008 za James, James 2012).

Adele Jones postuluje, żeby prowadząc badania z udziałem dzieci jako badaczy, bezwzględnie pamiętać o następujących dziesięciu kwestiach: (1) rola dzieci i cel ich zaangażowania $\mathrm{w}$ proces badawczy powinny być dokładnie sprecyzowane; (2) wszyscy uczestnicy projektu badawczego po- winni zgadzać się co do tego, które dzieci i dlaczego akurat one biorą udział w projekcie badawczym; (3) dzieci, a także dorośli sprawujący nad nimi opiekę, powinni wyrazić zgodę na udział w przedsięwzięciu badawczym; (4) praca, którą dzieci wykonują w badaniu, powinna zostać uznana i doceniona, a dzieci powinny uzyskać za nią tylko korzyści niematerialne (np. w postaci możliwości zwiększenia swoich kompetencji, poszerzenia umiejętności, doświadczenia czegoś ciekawego i rozwijającego, uzyskania zaświadczenia o szkoleniu czy certyfikatu uczestnictwie w projekcie), ale również wymierną materialną rekompensatę za czas i wysiłek włożony $\mathrm{w}$ badanie (w postaci pieniędzy lub bonów zakupowych - to powinno zostać uzgodnione z nimi i ich dorosłymi opiekunami); (5) zadania przydzielanie dzieciom powinny być odpowiednie dla nich i możliwe przez nie do wykonania, dostosowane do ich przekonań, wieku, możliwości oraz wybrane z uwzględnieniem czynników o charakterze społecznym i kulturowym; (6) używany przez członków zespołu badawczego język, metody i cały przebieg procesu badawczego powinny być zrozumiałe dla dzieci; (7) dzieci powinny otrzymać właściwe wsparcie, ułatwiające im udział $\mathrm{w}$ badaniu $\mathrm{w}$ roli badaczy w wymiarze praktycznym (umiejętności, wiedza, inne potrzebne zasoby) oraz dyskursywnym (refleksja na temat władzy, praw, pojęć i perspektyw badawczych); (8) należy wciąż upewniać się, że w trakcie badania dzieciom nie dzieje się krzywda, nie są wykorzystywane, nie jest na nie wywierana presja ani nie sa do niczego zmuszane, oraz że nie są poddawane manipulacjom ze strony dorosłych; (9) należy stworzyć system wsparcia dzieci-badaczy, z którego można w razie potrzeby szybko skorzystać; (10) trzeba zadbać o to, żeby wspólnie z dziećmi ustalić, jak bardzo badanie oraz one same jako badacze mogą zaingerować 
w życie badanych - innych dzieci (Jones 2004: 129). Dodatkowo, prowadząc badania, do których włącza się dzieci w roli badaczy, należy pamiętać, że to dorośli, nie dzieci, są odpowiedzialni za proces badawczy na każdym z jego etapów (Jones 2004). Wiele kwestii związanych z włączaniem dzieci jako współtwórców badań nie ma jednoznacznego rozstrzygnięcia i budzi kontrowersje. Na przykład: czy dzieci-badacze powinni być traktowani jak pracownicy? Czy powinni dostawać wynagrodzenie? Kto ma prawo do zebranego przez dzieci materiału badawczego? (James, James 2012). Niemniej jednak nadrzędną zasadą w badaniach z udziałem dzieci, również $\mathrm{w}$ badaniach z udziałem dzieci jako badaczy, jest zapewnienie im fizycznego i psychologicznego bezpieczeństwa (Mason 2002 za James, James 2012).

Dzieci bywają włączane jako badacze w projekty badawcze na różnych ich etapach oraz w różnych rolach. Czasami biorą udział w badaniach terenowych, w roli prowadzących wywiady, obserwacje czy też stosując inne metody zbierania lub wywoływania danych $\mathrm{w}$ interakcji $\mathrm{z}$ innymi dziećmi. W literaturze przedmiotu znajdujemy również przykłady przedsięwzięć badawczych, w ramach których dzieci biorą udział w tworzeniu koncepcji badawczej (badania dzieci sprawujących opiekę nad zależnymi członkami rodziny [Jones, Jeyasingham, Rajasoorija 2002 za Jones 2004]), interpretacji zebranych danych (badanie dzieci-pracowników [International Labor Organization 2002 za Jones 2004]), upowszechnianiu wyników badania (badania skutków migracji zarobkowych rodziców dla zdrowia psychicznego dzieci [Jones, Sharpe, Sorgen 2003 za Jones 2004]). Adele Jones zwraca uwagę na fakt, że dyseminacja wyników badań przybiera różne formy, w zależności od tego, na jaką grupę odbiorców jest nastawiona (np. naukowców, twórców polityk publicznych, uczestników badań, innych podmiotów). W przypadku badania prowadzonego z udziałem nastolatków w Trynidadzie, którego celem było zidentyfikowanie czynników odpowiedzialnych za rozwój depresji u wczesnych nastolatków, wyjazd zarobkowy rodziców/opiekunów był tym zjawiskiem, które okazało się mocno niekorzystnie wpływać na zdrowie psychiczne dzieci. W efekcie realizacji badania stwierdzono również, że doświadczający depresji nastolatkowie mieli poczucie osamotnienia w chorobie; uważali, że o chorobie nie mogą mówić otwarcie oraz że jest ona bagatelizowana lub wręcz ignorowana przez dorosłych. Zespół badawczy przygotował więc prezentację wyników badania dla członków rodzin, opiekunów i nauczycieli dzieci chorujących na depresję w formie akcji artystycznej - interaktywnego performance`u zrealizowanego przez instytucję teatralną. Podczas przedstawienia profesjonalni aktorzy wcielili się w role nastolatków, których rodzice wyemigrowali do pracy, i z ich perspektywy przedstawili doświadczane przez nich trudności, kryzysy i chorobę. W pewnym momencie profesjonalnych aktorów zastępowali na scenie sami uczestnicy badania, którzy we własnym imieniu kontynuowali opowieści. Dzięki temu działaniu doświadczenia i problemy badanych zostały wypowiedziane i wysłuchane, a kontekst, w jakim tego dokonano, wzmocnił i ulegitymizował ich przekaz (Jones 2004).

Zamiast podsumowania tej części tekstu chciałabym podkreślić znaczenie wewnętrznego zróżnicowania grupy/kategorii, jaką stanowią „dzieci”, ze względu na wiek, płeć, status społeczny, rasę/etniczność, stan zdrowia i wiele innych czynników. W ramach nowych studiów nad dzieciństwem mówi się o „dzieciństwach" (childhoods), podkreślając różnorodność (diversity) dziecięcych doświadczeń (James, James 
2012: 46-48). Prowadzenie badań z udziałem dzieci może oferować badaczom i badaczkom poczucie poznania „autentycznej” dziecięcej perspektywy, co grozi wpadnięciem w pułapkę uniwersalizacji doświadczeń, poglądów i wiedzy dzieci biorących udział $\mathrm{w}$ danym badaniu oraz ekstrapolacją jego wyników na „dzieci” w ogóle. Myślenie o dzieciach w kategorii homogenicznej grupy nie pozwala również właściwie przygotować się do badań z udziałem dzieci jako do procesu, w którym dzieci rywalizują, walczą o władzę i przywództwo w grupie, realizują własne interesy, wykluczają innych. Głosy dzieci mogą być „wyciszane” nie tylko przez dorosłych, ale i przez inne dzieci, czego przykład stanowi opisane przez Martę Rakoczy (2017) doświadczenie przygotowywania przez dzieci w Muzeum Narodowym w Warszawie wystawy „W muzeum wszystko wolno", kiedy pomysły najmłodszych uczestników projektu były przez starszych marginalizowane i unieważniane.

\section{Zakończenie}

$\mathrm{Na}$ zakończenie zaprezentuję ogólne wnioski płynące z wywiadów eksperckich, które zrealizowałam, przygotowując się do badań z udziałem dzieci. W wywiadach wzięli udział badacze i badaczki $\mathrm{z}$ doświadczeniem $\mathrm{w}$ realizacji badań naukowych i działań partycypacyjnych z udziałem dzieci, reprezentujący różne dyscypliny naukowe i obszary praktyki, pracujący $\mathrm{w}$ instytucjach o różnym charakterze. Wywiady przybierały formę dyskusji, czasem wręcz konsultacji. Wszystkie rozmowy przeprowadziłam online ze względu na pandemię i lockdown. Poniżej zebrałam wątki, które pojawiały się w rozmowach z ekspertami, czyniąc z nich rodzaj podsumowania powyższych rozważań oraz sposób na uwypuklenie lub uzupełnienie poruszonych we wcześniejszych częściach tekstu kwestii.
Każdy uczestnik/uczestniczka badania w nieco innym miejscu lokalizował/lokalizowała największe wyzwania związane z realizacją badań z udziałem dzieci i skoncentrowanych na dzieciach. Świadczy to być może o bardzo świadomym i pogłębionym, a przez to zindywidualizowanym podejściu do własnej praktyki badawczej, o różnym zakresie doświadczeń (projekty badawcze dotyczące różnych tematów związanych z funkcjonowaniem dzieci, indywidualnie lub zespołowo, realizowane różnymi metodami i technikami, usytuowane w różnych tradycjach badań społecznych, realizowane w różnych kontekstach instytucjonalnych, w różnym czasie, w różnych rolach i na różnym etapie rozwoju kariery zawodowej) oraz być może o tym, że indywidualne cechy (osobowościowe, własne doświadczenia, fakt posiadania/nieposiadania dzieci) również wpływają na to, które elementy/aspekty badań z dziećmi są dla nas szczególnie trudne lub przeciwnie - łatwe lub prawie „naturalne”. Tym niemniej wszystkie badane osoby podkreślały, że prowadzenie badań z udziałem dziećmi upodmiotawia najmłodszych, jest formą realizacji prawa dzieci do bycia wysłuchanymi, a efekty udziału dzieci w badaniu (np. wzrost ich poczucia sprawczości, podniesienie ich statusu w społeczeństwie, uzyskanie cennej wiedzy na temat ich odczuć, doświadczeń, perspektywy wiedzy) są bezsprzecznie wartościowe, dlatego bezwzględnie należy podejmować badania z udziałem dzieci.

Uczestniczki i uczestnicy wywiadów uważali, że choć udział w badaniu może stanowić dla dzieci pewne ryzyko, to jednak rozmowa $z$ otwartym, życzliwym, dobrze nastawionym, odpowiednio przygotowanym metodologicznie oraz świadomym kwestii etycznych dorosłym na ogół nie jest dla dziecka sytuacją zagrażającą. Moje rozmówczynie i rozmówcy zgadzali się, że prowadzenie 
badań z dziećmi nie jest łatwe i że proces ten wymaga przemyślenia wielu kwestii przed ich rozpoczęciem, uważności, wrażliwości, reagowania na zachowania werbalne i niewerbalne uczestników badania, elastyczności, przygotowania i gotowości do zastosowania wielu możliwych scenariuszy w trakcie badania, a także wewnętrznej zgody badacza/badaczki na to, że badanie może się nie udać lub może w ogóle nie dojść do skutku. Badania z udziałem dzieci w szczególny sposób wymagają podejmowania przez badacza/badaczkę „na gorąco” indywidualnych decyzji, korzystania z własnego wyczucia, doświadczenia, czasami intuicji. Ważne jest także, żeby badacz/badaczka posiadali znajomość instytucjonalnego otoczenia dzieci - uczestników badań. Ekspertki i eksperci podkreślali, że dzieci wyrażają swoją wolę i podmiotowość, choć nie zawsze wprost. Jeżeli nie zechca, to nie udzielą informacji lub będą odpowiadać zdawkowo, ograniczą swoją aktywność, będą milczeć. Badania z udziałem dzieci czasami pozwalają im się wypowiedzieć na tematy objęte społecznym lub rodzinnym tabu, o których dorośli boją się z nimi rozmawiać, co jest dla dzieci bardzo ważne i potrzebne. Istotnym „elementem” badań z udziałem dzieci są otaczający je dorośli - rodzice, opiekunowie, wychowawcy, nauczyciele. Oprócz oczywistej kwestii - udzielenia zgody koniecznej do włączenia dziecka do badania, dorośli wpływają na proces badania na inne sposoby, na przykład mogą celowo lub nieświadomie kształtować przebieg badania oraz warunkować jakość i treść zebranych danych. Rodzice i inni dorośli postrzegani są przez badaczki i badaczy praktykujących badania $\mathrm{z}$ udziałem dzieci w wielowymiarowy sposób: jako poplecznicy, osoby, z którymi warto współpracować, ale też jako „elementy” pola badawczego, które czasami należy naturalizować. Nieprzychylne lub obojętne nastawienie dorosłych może zniechęcić lub zmniejszyć poziom zaangażowania dzieci $\mathrm{w}$ badanie. $\mathrm{W}$ badaniach $\mathrm{z}$ udziałem dzieci sprawdzą się zarówno „klasyczne” metody badawcze, takie jak wywiad, obserwacja, zogniskowany wywiad grupowy, jak i różnorodne formy badań partycypacyjnych, wykorzystujące aktywność fizyczną, zabawę, wykonywanie prac plastycznych, rejestrowanie dźwięków lub/i obrazów oraz tradycyjne badania etnograficzne, wymagające nawiązania relacji, spędzania wspólnie większej ilości czasu, stania się przez badacza/badaczkę członkiem/członkinią dziecięcej grupy.

Uczestniczki i uczestnicy wywiadów eksperckich prezentowali niejednolite stanowiska w następujących kwestiach:

- omówionego wcześniej zagadnienia wynagrodzenia/rekompensaty/zapłaty za udział dziecka w badaniu (w ich wypowiedziach pojawiały się różne opinie dotyczące tego, co dziecko w związku z udziałem w badaniu powinno otrzymać oraz czy dziecko/jego rodzice przed badaniem powinno/powinni być poinformowane/poinformowani, że otrzyma/ją coś w zamian za udział w badaniu);

- zgody na udział dziecka w badaniu udzielanej przez dorosłych (większość badanych uważała, ze zgoda rodziców lub innych opiekunów prawnych jest bezwzględnie konieczna, ale pojawiły się też głosy odrębne, mówiące, że czasami zgody dorosłego może nie dać się uzyskać, na przykład w badaniach dzieci ulicy, lub kiedy nie powinno się o nią zabiegać, wiedząc, że sam proces zwrócenia się o zgodę opiekuna na udział w badaniu może zaszkodzić dziecku, na przykład w przypadku badania dotyczącego sytuacji 
niepełnoletnich osób homoseksualnych, jeżeli dziecko nie ujawniło swojej orientacji seksualnej przed opiekunami);

- nawiązywanie głębszej relacji, „zaprzyjaźnianie się" lub „zakolegowywanie się” z dzieckiem przez dorosłego badacza (niektórzy uznawali je za konieczny warunek dobrych badań, inni za rodzaj nadużycia, oszustwa, niewłaściwą strategię);

- włączania psychologa lub innego „profesjonalnego pomagacza” w skład zespołu projektowego prowadzącego badania z dziećmi (niektórzy rekomendowali włączenie do zespołu profesjonalisty, który byłby w stanie zadbać o dobrostan emocjonalny uczestników badania i badaczy, szczególnie w przypadku badań o trudnej tematyce, inni uważali za słuszne posiadać aktualną listę kontaktów do specjalistów, do których w razie potrzeby można się zwrócić, jednak bez nawiązywania trwałej, formalnej współpracy);

- znaczenia faktu, że badacz/badaczka jest rodzicem dla prowadzenia przez niego/nią badań z udziałem dzieci (ten czynnik można uznać za potencjalną przeszkodę - status rodzica może powodować „nadwrażliwość” wobec badanych dzieci, zagrożenie postrzeganiem wszystkich badanych przez pryzmat doświadczeń własnych dzieci, brak „świeżości", nadmierne chronienie badanych lub zbyt duże zaangażowanie emocjonalne, jeśli badane dziecko znajduje się w sytuacji trudnej, nadmierny nacisk na udzielenie mu pomocy; bycie rodzicem można też uznać za doświadczenie przydatne $\mathrm{w}$ badaniach z udziałem dzieci, zwiększające wyczulenie na kwestie etyczne i dbałość o dobrostan dziecka w procesie badania).

Dzieciństwo i doświadczenia dzieci stanowią ważny obszar badań społecznych, które nabierają szczególnego znaczenia $\mathrm{w}$ okresie pandemii Covid-19. Utrzymujące się poczucie zagrożenia, długie okresy izolacji, diametralna zmiana trybu życia, ograniczona aktywność fizyczna i społeczna, nauczanie zdalne i wiele innych skutków rozprzestrzeniania się wirusa obniżyły jakość życia dzieci (np. Makaruk, Włodarczyk, Szredzińska 2020). Do publicznego dyskursu dotyczącego konsekwencji pandemii przedostają się głosy na temat łamania praw dzieci oraz ich pogarszającego się stanu zdrowia, w tym zdrowia psychicznego oraz problemów w relacjach społecznych ${ }^{9}$. W przestrzeni publicznej pojawiają się również wezwania do podejmowania działań na rzecz poprawy sytuacji dzieci $\mathrm{w}$ czasie pandemii. $\mathrm{Na}$ pewno warto i należy je podejmować, ale projektowanie i realizacja jakichkolwiek działań interwencyjnych, naprawczych lub profilaktycznych powinna być poprzedzona diagnozą, konieczne jest zatem posiadanie rzetelnej wiedzy dotyczącej tego, jak dzieci się czują, w jakim są stanie, jakich doświadczają problemów i czego potrzebują. Taką wiedzę uzyskamy przede wszystkim dzięki właściwie przeprowadzonym badaniom skoncentrowanym na dzieciach, badaniom $\mathrm{z}$ udziałem dzieci, a być może również dzięki projektom badawczym z dziećmi w rolach badaczy.

\footnotetext{
${ }^{9} \mathrm{~Np}$. „Mały Polaku, jesteś nieważny. Czego dzieciaki nauczyły się w szkole przez ostatnie dwa miesiące", Natalia Mazur, 16 maja 2020, „Wolna sobota”, magazyn "Gazety Wyborczej”; „Dzieci wciąż głosu nie mają. Czy w ogóle je lubimy?", wywiad Joanny Cieśli z Ewą Maciejewską-Mroczek, Polityka 11 lipca 2020 r., https://www.polityka.pl/tygodnikpolityka/ spoleczenstwo/1961732,1,dzieci-wciaz-glosu-nie-maja-czy-wogole-je-lubimy.read (dostęp 13.07.2021).
} 
Badania skoncentrowane na dzieciach, badania z udziałem dzieci, dzieci jako badacze. Etyczne i metodologiczne aspekty badań prowadzonych w nurcie nowej socjologii dzieci i dzieciństwa

\section{Bibliografia}

American Sociology Association (1999) Code of Ethics (https:// www.asanet.org/sites/default/files/savvy/images/asa/docs/pdf/ CodeofEthics.pdf) [dostęp 19.10.2021].

Babbie Earl (1995) The Practice of Social Research. Belmont, London, Victoria, Ontario, Mexico, Bonn, Singapore, Tokyo: Wadsworth Publishing Company.

Boni Zofia (2018) Negocjowanie „zdrowego jedzenia” w warszawskich rodzinach [w:] Magdalena Radkowska-Walkowicz, Maria Reimann, red., Dzieci i zdrowie. Wstęp do childhood studies. Warszawa: Oficyna Naukowa, s. 172-195.

Brzezińska Anna Izabela, Toeplitz Zuzanna, red. (2007) Problemy etyczne w badaniach $i$ interwencji psychologicznej wobec dzieci i młodzieży. Warszawa: Wydawnictwo SWPS Academica.

Brzozowska-Brywczyńska Maja (2014) Dziecięce obywatelstwo: kilka refleksji na marginesie dziecięcej partycypacji. „Acta Universitatis Lodziensis. Folia Sociologica", nr 49, s. 11-27.

Bunio-Mroczek Paulina (2016) Wczesne rodzicielstwo-zagrożenie czy szansa? Nastoletni rodzice z łódzkich enklaw biedy. Łódź: Wydawnictwo Uniwersytetu Łódzkiego.

Bunio-Mroczek Paulina (2017) Od redaktora. Aktualne teoretyczne, metodologiczne i tematyczne podejścia w badaniach dzieciństwa imłodzieży w perspektywie jakościowej . „Przegląd Socjologii Jakościowej”, t. 13, nr 4, s. 8-13. DOI: http://dx.doi.org/10.18778/1733-8069.13.4.01 (www.przegladsocjologiijakosciowej.org) [dostęp 30.11.2017].

Bunio-Mroczek Paulina (2021) Dzieci w procesie odnowy miasta. Na przykładzie Gminnego Programu Rewitalizacji miasta Łodzi. Odczyt zaprezentowany 20.05.2021 r. podczas XXXVIII Konferencji Polityków Społecznych i Jubileuszu Instytutu Gospodarstwa Społecznego pt. „Teoria i praktyka polityki społecznej”, 19-21 maja $2021 \mathrm{r}$.

Corsaro William A. (2015) The Sociology of Childhood. Fourth Edition. London, Thousand Oaks, New Delhi, Singapore: SAGE.

Dzieci wciąż głosu nie maja. Czy wo oóle je lubimy? Wywiad Joanny Cieśli z Ewą Maciejewską-Mroczek. „Polityka”, 11 lipca 2020 r. (https://www. polityka.pl/tygodnikpolityka/spoleczenstwo/1961732,1,dzieci-wciazglosu-nie-maja-czy-w-ogole-je-lubimy.read) [dostęp 13.07.2021].

Favretto Anna Rosa, Fucci Stefania, Zaltron Francesca (2018) Codziennie praktyki w zdrowiu i chorobie. Metodologiczne rozważa- nia nad kompetencjami dzieci [w:] Magdalena Radkowska-Walkowicz, Maria Reimann, red., Dzieci i zdrowie. Wstęp do childhood studies. Warszawa: Oficyna Naukowa, s. 80-100.

Gabriel Norman (2017) The Sociology of Early Childhood. Critical Perspectives. London, Thousand Oaks, New Delhi, Singapore: SAGE.

James Alison, James Adrian (2012) Key concepts in Childhood Studies. Second Edition. London, Thousand Oaks, New Delhi, Singapore: SAGE.

Jemielniak Dariusz, red. (2012) Badania jakościowe. Podejścia i teorie. Warszawa: Wydawnictwo Naukowe PWN.

Jones Adele (2004) Involving Children and Young People as Researchers [w:] Sandy Fraser i in., eds., Doing Research with Children and Young People. London, Thousand Oaks, New Delhi: SAGE, s. 113-130.

Kodeks dobrych praktyk $w$ badaniach $z$ dziećmi prowadzonych $z$ perspektywy nauk społecznych (w tym interdyscyplinarnych childhood studies, etnografii, antropologii kulturowej, socjologii, Interdyscyplinarny Zespót Badań nad Dzieciństwem (Ewa Maciejwska-Mroczek, Magdalena Radkowska-Walkowicz, Maria Reimann, Anna Witeska-Młynarczyk, współpraca: Zofia Boni, Anna Krawczyk) (2018) [w:] Magdalena Radkowska-Walkowicz, Maria Reimann, red., Dzieci i zdrowie. Wstęp do childhood studies. Warszawa: Oficyna Naukowa Warszawa, s. 27-34.

Kodeks etyki socjologa. Uchwalony przez Walne Zgromadzenie Delegatów Polskiego Towarzystwa Socjologicznego dnia 25 marca 2012 r. (https://pts.org.pl/wp-content/uploads/2016/04/ kodeks.pdf. [dostęp 16.07.2021].

Liamputtong Pranee (2007) Researching the Vulnerable. A Guide to Sensitive Research Methods. London, Thousand Oaks, New Dehli: SAGE.

Lisek Michalska Jolanta (2012) Etyczne aspekty badań fokusowych z udziałem dzieci i młodzieży. „Acta Universitatis Lodzensis, Folia Sociologica", nr 42, s. 33-61.

Maciejewska-Mroczek Ewa (2018) Badania grupowe z udziałem dzieci. Aspekty etyczne i praktyczne [w:] Magdalena Radkowska-Walkowicz, Maria Reimann, red., Dzieci i zdrowie. Wstęp do childhood studies. Warszawa: Oficyna Naukowa, s. 35-60.

Maciejewska-Mroczek Ewa, Reimann Maria (2016) Jak zgadzaja i nie zgadzaja się dzieci. O (nie)równowadze sit i świadomej zgodzie w bada- 
niach z dziećmi. „Przegląd Socjologii Jakościowej”, t. 12, nr 4, s. 42-55 (www.przegladsocjologiijakosciowej.org) [dostęp 20.06.2021].

Makaruk Katarzyna, Włodarczyk Joanna, Szredzińska Renata (2020) Negatywne doświadczenia młodzieży w trakcie pandemii. Raport z badań ilościowych, Fundacja Dajemy Dzieciom Siłe (https://fdds. pl/_Resources/Persistent/5/0/0/e/500e0774b0109a6892ce777b0d8595f528adea62/Negatywne-doswiadczenia-mlodziezy-w-trakciepandemii.-Raport-z-badan-ilosciowych-1.pdf) [dostęp 13.07.2021].

Mazur Natalia (2020) Mały Polaku, jesteś nieważny. Czego dzieciaki nauczyły się w szkole przez ostatnie dwa miesiace. "Wolna sobota”, 16 maja 2020 (https://wyborcza.pl/magazyn/7,124059,25949206,maly-polaku-jestes-niewazny-czego-dzieciaki-nauczyly-sie-w.html) [dostęp 20.05.2020].

Mikołajczyk-Lerman Grażyna (2017) Konwencja o prawach dziec$k$ a a realizacja praw dziecka $z$ niepetnosprawnościa w relacjach rówieśniczych. „Przegląd Socjologii Jakościowej”, t. 13, nr 4, s. 30-47. DOI: http://dx.doi.org/10.18778/1733-8069.13.4.03 (www.przegladsocjologiijakosciowej.org) [dostęp 30.11.2017].

Petelewicz Marta (2016) Jakość życia dzieci a status społeczno-ekonomiczny rodziny. Teoria i badania. Łódź: Wydawnictwo Uniwersytetu Łódzkiego.
Rakoczy Marta (2017) Czy w muzeum wszystko wolno? Problemy z nowoczesnym pajdocentryzmem. „Widok. Teorie i Praktyki Kultury Wizualnej", nr 19. DOI: https://doi.org/10.36854/widok/2017.19.550 (https://www.pismowidok.org/pl/archiwum/2017/19-obrazy-dla-dzieci/czy-w-muzeum-wszystko-wolno-problemy-znowoczesnym-pajdocentryzmem) [dostęp: 20.10.2021].

Reimann Maria (2018) Gruby i chudy, czyli o tym, jak dzieci wyobrażaja sobie zdrowego i niezdrowego człowieka [w:] Magdalena Radkowska-Walkowicz, Maria Reimann, red., Dzieci i zdrowie. Wstęp do childhood studies. Warszawa: Oficyna Naukowa s. 138-149.

Statement of Ethical Practice (2017) British Sociological Association (https://www.britsoc.co.uk/media/24310/bsa_statement_of_ ethical_practice.pdf) [dostęp 19.10.2021].

Walker Marion i in. (2012) "It came up to here": learning from children's flood narratives. "Children's Geographies”, vol. 10, no. 2, s. $135-150$.

Witeska-Młynarczyk Anna (2018) Etyka dnia codziennego w badaniach etnograficznych $z$ dziećmi z diagnoza ADHD. Opis warstwowy [w: ] Magdalena Radkowska-Walkowicz, Maria Reimann, red., Dzieci $i$ zdrowie. Wstęp do childhood studies. Warszawa: Oficyna Naukowa, s. 61-79.

\title{
Cytowanie
}

Bunio-Mroczek Paulina (2021) Badania skoncentrowane na dzieciach, badania z udziałem dzieci, dzieci jako badacze. Etyczne i metodologiczne aspekty badań prowadzonych w nurcie nowej socjologii dzieci i dzieciństwa. „Przegląd Socjologii Jakościowej”, t. 17, nr 4, s. 6-26 [dostęp dzień, miesiąc, rok]. Dostępny w Internecie: ‘www.przegladsocjologiijakosciowej.org〉. DOI: https://doi.org/10.18778/1733-8069.17.4.01

\section{Child-Focused Research, Research with Children, Children as Researchers: The Ethical and Methodological Aspects of Empirical Studies in the Field of New Sociology of Children and Childhood}

\begin{abstract}
Research on childhood, including research with the participation of children, is a developing area of scientific activity undertaken within the framework of interdisciplinary 'new childhood studies'. It is currently based on the concept of a child as an active social actor and on the principles of the 1989 UN Convention on the Rights of the Child. Conducting research focused on children, research with children, as well as research where children assume the role of researchers (co-authors of the research project) requires a deeper reflection on ethics and methodology. As a minority group subjected to discrimination and marginalization in societies and cultures, children are considered to be "sensitive" or "vulnerable" research participants. The article is based on the analysis of the literature on new childhood studies as well as on qualitative interviews with experts (researchers experienced in childhood research). In the paper, I present important ethical and methodological issues and dilemmas of research with children, along with examples of solutions adopted in this regard within new childhood studies.
\end{abstract}

Keywords: sociology of children and childhood, research with children, child-focused research, research ethics, research methodology 